\title{
Advanced targeted, cell and gene-therapy approaches for pediatric hematological malignancies: results and future perspectives
}

\section{Chiara F. Magnani, Sarah Tettamanti, Francesca Maltese, Nice Turazzi, Andrea Biondi and Ettore Biagi *}

Department of Pediatrics, Centro di Ricerca Matilde Tettamanti, San Gerardo Hospital, University of Milano-Bicocca, Monza, Italy

\section{Edited by:}

Peter Bader, University Hospital for

Childhood and Adolescence

Medicine, Germany

Reviewed by:

Roland Meisel, University Hospital

Duesseldorf, Germany

Gene P. Siegal, University of Alabama

at Birmingham, USA

\section{*Correspondence:}

Ettore Biagi, Department of

Pediatrics, Centro di Ricerca Matilde

Tettamanti, San Gerardo Hospital,

University Milano-Bicocca, via

Pergolesi 33, Monza 20052, Italy.

e-mail: e.biagi@hsgerardo.org

\begin{abstract}
Despite the survival of pediatric patients affected by hematological malignancies being improved in the last 20 years by chemotherapy and hematopoietic stem cell transplantation, a significant amount of patients still relapses. Treatment intensification is limited by toxic side effects and is constrained by the plateau of efficacy, while the pipeline of new chemotherapeutic drugs is running short. Therefore, novel therapeutic strategies are essential and researchers around the world are testing in clinical trials immune and genetherapy approaches as second-line treatments. The aim of this review is to give a glance at these novel promising strategies of advanced medicine in the field of pediatric leukemias. Results from clinical protocols using new targeted "smart" drugs, immunotherapy, and gene therapy are summarized, and important considerations regarding the combination of these novel approaches with standard treatments to promote safe and long-term cure are discussed.
\end{abstract}

Keywords: advanced therapy, pediatric leukemia, novel drugs, adoptive immunotherapy, chimeric antigen receptor gene therapy

\section{INTRODUCTION}

Current treatments of childhood hematological malignancies are based on standardized regimens with poly-chemotherapeutic drugs, developed over the last 40 years. Significant progress has been achieved in this field, particularly as a result of the combination with hematopoietic stem cell transplantation (HSCT) which led to an increase of more than $80 \%$ in survival rate of acute lymphoblastic leukemia (ALL) and to a greater than $60 \%$ remission of the less common acute myeloid leukemia (AML) (Wayne et al., 2008). Changes in the timing scheme together with dose scaling, combination of different chemotherapeutic drugs, and modifications in their formulations resulted in multi-agent-chemotherapy protocols, which allowed better disease management and increased survival prognosis (Lee-Sherick et al., 2010). Immunotherapy with HSCT in high-risk patients has decreased the risk of relapse due to its strong graft-versus-leukemia (GVL) effects, even if it often correlates with a higher incidence of treatment-related mortality (Leung et al., 2011).

Along with cytotoxic treatments, high standards of supportive care, particularly antimicrobial prophylaxis (Unguru, 2011), have highly improved the quality of the current therapeutic approaches. Further progresses have been reached also thanks to the translation of recent findings from bench to bedside, paving the way for the development of novel randomized clinical trials involving patients with more aggressive diseases. Furthermore, patients diagnosed with leukemia are treated with a step-by-step protocol based on the characteristics of the disease at onset and the minimal residual disease (MRD) that is detected after first-line drugs. Such a strategy of risk-oriented stratification is the first step toward the concept of personalized medicine and is currently leading to lower rate of relapse, particularly in ALL (Locatelli et al., 2012).

Despite the important efficacy of the current treatments, relapse still occurs and a significant number of patients falls back (Wayne et al., 2008). Escalation of the current treatments seems not to add any further advantage. In these cases, alternative treatments based on targeted agents and advanced protocols of gene and adoptive cell therapy (ACT) are strongly warranted.

In this review, we aim to summarize novel advanced drugs and treatments that are available or are considered promising strategies. In addition we provide proof of concept for future integration of several novel approaches and standard treatments in a context of "consolidative immunotherapy."

\section{NEW ANTIMETABOLITES, NUCLEOSIDE ANALOGS, AND "SMART" DRUGS}

Nowadays antimetabolites are considered one of the most effective category of drugs available for treating hematological malignancies. Clofarabine was synthesized as a next-generation purine nucleoside analog (Montgomery et al., 1992; Kantarjian et al., 2007). In 2004 this drug was approved by the FDA for the treatment of pediatric relapsed or refractory ALL patients. Phase I and II trials with clofarabine showed an overall response rate of $30 \%$ as single agent for refractory pediatric ALL and AML (Jeha et al., 2004, 2006). Combination with cyclophosphamide/etoposide, evaluated in phase I (Hijiya et al., 2009), phase II (Locatelli et al., 2009; Hijiya et al., 2011), and phase III trials (NCT01406756) ${ }^{1}$, revealed encouraging overall response rates, near 50\% for ALL and 100\% for five

${ }^{1}$ http://www.clinicaltrials.gov 
AML patients, despite significant treatment-related adverse effects, such as infections, neutropenia, and hepatotoxicity. Decitabine, a DNA methyltransferases inhibitor (Pinto et al., 1984; Schafer et al., 2010), has been used as epigenetic priming in combination with chemotherapy in kids with AML (NCT01177540; NCT00943553). Preliminary data demonstrated that the treatment is well tolerated; however, clinical responses were similar to the control arm of the study (Gore et al., 2012). Novel and advanced treatments against hematological malignancies focus on targeted therapy, characterized by selection of specific molecular targets. Such drugs are considered "smart" since they selectively target cancer signaling pathways or expression of genes specifically overexpressed in cancerous and not healthy cells (Villanueva, 2012). Among them, tyrosine kinase inhibitors (TKI), which act as signal transduction inhibitors, target enzymes overexpressed by malignant tumors involved in uncontrolled cell proliferation, inhibition of apoptosis, and cell adhesion (Hunter, 1998; Arora and Scholar, 2005). Early success of the first targeted agent Imatinib mesylate in CML and $\mathrm{Ph}^{+}$ALL treatment (O'Brien et al., 2003; Wassmann et al., 2004) demonstrated the efficacy of inhibiting BCR/ABL1 (p210), the constitutive active kinase protein produced by the abnormal fusion of the two genes. These results were confirmed also in pediatric patients with $\mathrm{Ph}^{+}$ALL, improving 3-year event-free survival (EFS) from $35 \%$ of the historical controls to $80 \%$ with no increased toxicity (Schultz et al., 2009). However, the presence of mechanisms of Imatinib resistance and transient responses (Walz et al., 2006) encouraged the development of second generation TKI, such as Dasatinib (Olivieri and Manzione, 2007), Nilotinib (Weisberg et al., 2005), and Bosutinib (Redaelli et al., 2009). A pediatric phase I trial on $\mathrm{Ph}^{+} \mathrm{CML}$ and ALL patients carried out by the Children's Oncology Group (COG) revealed that the majority of children with CML achieved a clinical response after oral administration of Dasatinib (Aplenc et al., 2011). Two more phase II and one phase III pediatric clinical trials are currently ongoing with the aim to evaluate whether Dasatinib is safe and effective in the treatment of $\mathrm{Ph}^{+} \mathrm{ALL}$ and $\mathrm{CML}$, alone or in combination with standard chemotherapy (NCT00777036; NCT01460160; NCT00720109). In this context, continuous dose Dasatinib has been shown to be safe and feasible in combination with intensive chemotherapy in pediatric $\mathrm{Ph}^{+}$ALL (Slayton et al., 2012), demonstrating that early introduction of TKI on day 15 of induction and substitution of Dasatinib for Imatinib led to improved induction remission rates from 89 to $98 \%$, and induction negative MRD rates from 25 to $59 \%$. Certainly, Dasatinib represents one of the most promising drugs in the context of small smart molecules for refractory $\mathrm{Ph}^{+}$ALL.

Another important molecule is represented by FMS-like tyrosine kinase 3 (FLT3), in which point mutations and internal tandem duplications lead to the encoding of a constitutive active kinase, both in childhood ALL and AML, which is associated with poor prognosis (Levis and Small, 2003). Promising FLT3 inhibitors currently tested for childhood malignancies are Lestaurtinib (Levis et al., 2002), Sorafenib (Rubnitz, 2012), and Midostaurin (Fabbro et al., 2000). Sorafenib has been recently evaluated in combination with clofarabine and cytarabine, showing response in pediatric relapsed/refractory AML (Inaba et al., 2011). Trials evaluating oral Lestaurtinib (phase III) in infant mixed lineage leukemia-rearranged (MLL-R) ALL, Sorafenib (phase III) in patients with AML, and Midostaurin (phase I/II) in relapsed pediatric leukemia are currently recruiting patients (NCT00557193; NCT01371981; NCT00866281).

\section{CANCER IMMUNOTHERAPY: MONOCLONAL ANTIBODIES AND CELL THERAPY}

Over the last decades, significant progress in understanding the complex involvement of the immune system in tumor surveillance has been made. This has led to novel approaches that exploit both the humoral and cell-mediated arms of adaptive immunity, such as monoclonal antibodies (mAbs), cancer vaccines, and ACT. The ultimate goal of immunotherapy is to decrease toxicity against normal tissues by eliciting specific responses against tumor associatedantigens (TAA) and to bypass the tumor immune escape/tolerance mechanisms (Dougan and Dranoff, 2009).

Rituximab (anti-CD20) (Dworzak et al., 2008) is currently applied for the treatment of $\mathrm{CD} 20^{+} \mathrm{B}$-cell lymphomas; several $m A b s$ targeting different TAAs have been proposed for pediatric patients in association with chemotherapy, such as anti-CD52 [Alemtuzumab (Law et al., 2012)] and CD22 [Epratuzumab (Scott et al., 2012)]. Rituximab has demonstrated to be active as single agent in pediatric B-NHL with $41.4 \%$ response rate (Meinhardt et al., 2010) and combined with chemotherapy in CD20 ${ }^{+} \mathrm{NHL}$ and leukemia with $60 \%$ response rate (Griffin et al., 2009). Alemtuzumab was evaluated as single agent in children with relapsed ALL, showing limited response with only 1 patient in complete remission out of 13-tested (Angiolillo et al., 2009). Thus, given the limitations of using mAbs as single agents in rapidly proliferative diseases, mAbs conjugated with cytotoxic agents, including antibody-drug conjugates (ADCs), immunotoxins, and radioimmunoconjugates (FitzGerald et al., 2011; Sharkey and Goldenberg, 2011), have been developed and tested in clinical trials, showing promising results in adults (Mackall, 2011; Orentas et al., 2012). The anti-CD22 immunotoxin, Moxetumomab pasudotox, achieved 29\% response rate (Wayne et al., 2011), whereas the anti-CD22 calicheamicin conjugate, Inotuzumab ozogamicin, showed 57\% response rate (Kantarjian et al., 2012) in relapsed/refractory ALL pediatric patients. The ADC Brentuximab vedotin in Hodgkin's lymphoma has been approved for commercial use after it demonstrated significant activity in adults (Younes et al., 2010) and it is currently evaluated in several pediatric clinical trials. Notably, the novel bi-specific T-cell engager (BiTE) represents, among all, one of the most promising approaches. This antibody simultaneously cross-links the $\mathrm{CD} 19^{+}$target and the $\mathrm{CD}^{+} \mathrm{T}$ cells, recruiting the effector cells to the tumor. A multicenter study involving Northern American and European institutions is ongoing (May et al., 2012). Table 1 summarizes the use of mAbs, ADCs, immunotoxins, and radioimmunoconjugates in pediatric clinical trials.

The promise of eliciting specific memory response by active immunotherapy using cancer vaccines has guided the development of different approaches, including vaccines composed of tumorspecific peptides, dendritic cells (DC) pulsed with peptides, and whole tumor cells (Rousseau and Brenner, 2005; Wayne et al., 2010). The results of the first three treated pediatric cases in the phase II trial using WT1 peptide vaccination plus HSCT showed 
Table 1 |The list represents a selection of the main trials for each single agent for novel approaches in pediatric hematological malignancies in the field of mAbs and derivates.

\begin{tabular}{|c|c|c|c|c|c|}
\hline Target & Malignancies & $\begin{array}{l}\text { mAbs, ADCs, immunotoxins, } \\
\text { radioimmunoconjugates }\end{array}$ & Published results & Location & $\begin{array}{l}\text { Trial number } \\
\text { and references }\end{array}$ \\
\hline CD19 & $\begin{array}{l}\text { Advanced } \\
\text { relapsed/refractory ALL or } \\
\text { CLL }\end{array}$ & $\begin{array}{l}\text { Yttrium Y } 90 \text { anti-CD19 } \\
\text { monoclonal antibody } \\
\text { BU12/111 In-BU-12 }\end{array}$ & $\begin{array}{l}\text { Terminated due to slow } \\
\text { accrual }\end{array}$ & $\begin{array}{l}\text { Masonic Cancer Center, } \\
\text { University of Minnesota }\end{array}$ & $\begin{array}{l}\text { NCT00643240 } \\
\text { Phase I }\end{array}$ \\
\hline $\begin{array}{l}\text { CD19+ } \\
\text { CD3 }\end{array}$ & $\begin{array}{l}\text { Relapsed/refractory } \\
\text { precursor B-cell ALL }\end{array}$ & $\begin{array}{l}\text { Blinatumomab } \\
\text { (BiTE = bi-specific antibodies) }\end{array}$ & $\begin{array}{l}\text { Currently recruiting } \\
\text { participants }\end{array}$ & $\begin{array}{l}\text { Amgen Research (Munich) } \\
\text { GmbH, Multicentric study }\end{array}$ & $\begin{array}{l}\text { NCT01471782 } \\
\text { Phase I/II }\end{array}$ \\
\hline \multirow[t]{6}{*}{ CD20 } & $\begin{array}{l}\text { Recurrent/refractory NHL } \\
\text { and ALL }\end{array}$ & $\begin{array}{l}\text { Rituximab (Rituxan®; } \\
\text { MabThera) associated to } \\
\text { chemotherapy }\end{array}$ & $\begin{array}{l}\text { Completed, } 20 \text { patients, } \\
\text { CR/PR 12/20 (60\%) }\end{array}$ & National Cancer Institute (NCI) & $\begin{array}{l}\text { NCT00058461 } \\
\text { Phase II (Griffin } \\
\text { et al., 2009) }\end{array}$ \\
\hline & B-cell ALL and NHL & Rituximab & 87 patients, $41.4 \%$ ORR & $\begin{array}{l}\text { Kinderklinik, Aachen, } \\
\text { Multicentric study }\end{array}$ & $\begin{array}{l}\text { NCT00324779 } \\
\text { Phase II (Meinhardt } \\
\text { et al., 2010) }\end{array}$ \\
\hline & $\begin{array}{l}\text { Relapsed/refractory } \\
\text { precursor B-cell ALL and } \\
\text { lymphoma }\end{array}$ & $\begin{array}{l}\text { Rituximab associated to } \\
\text { chemotherapy and } \\
\text { haploidentical NK cell infusion }\end{array}$ & $\begin{array}{l}\text { Currently recruiting } \\
\text { participants }\end{array}$ & $\begin{array}{l}\text { St. Jude Children's Research } \\
\text { Hospital }\end{array}$ & $\begin{array}{l}\text { NCT01700946 } \\
\text { Phase II }\end{array}$ \\
\hline & Relapsed ALL & $\begin{array}{l}\text { Rituximab associated to } \\
\text { chemotherapy }\end{array}$ & $\begin{array}{l}\text { The study has been } \\
\text { terminated }\end{array}$ & $\begin{array}{l}\text { Emory University Multicentric } \\
\text { study }\end{array}$ & $\begin{array}{l}\text { NCT01230788 } \\
\text { Phase I }\end{array}$ \\
\hline & $\begin{array}{l}\text { Refractory leukemia and } \\
\text { lymphoid malignancies } \\
\text { involving the central } \\
\text { nervous system }\end{array}$ & Intrathecal rituximab & $\begin{array}{l}\text { Currently recruiting } \\
\text { participants }\end{array}$ & M.D. Anderson Cancer Center & $\begin{array}{l}\text { NCT01596127 } \\
\text { Phase I/II }\end{array}$ \\
\hline & B-cell ALL and NHL & $\begin{array}{l}\text { Rituximab associated to } \\
\text { chemotherapy }\end{array}$ & $\begin{array}{l}\text { Currently recruiting } \\
\text { participants }\end{array}$ & Institut Gustave Roussy & $\begin{array}{l}\text { NCT01516580 } \\
\text { Phase III }\end{array}$ \\
\hline \multirow[t]{3}{*}{ CD22 } & ALL, NHL & $\begin{array}{l}\text { Moxetumomab pasudotox } \\
\text { (HA22; CAT80-15) }\end{array}$ & $\begin{array}{l}\text { Currently recruiting: } 21 \\
\text { patients treated, } 24 \% \\
\text { CR, 1\% PR }\end{array}$ & $\begin{array}{l}\text { National Cancer Institute } \\
\text { (NCl) Multicentric study }\end{array}$ & $\begin{array}{l}\text { NCT00659425 } \\
\text { Phase I Mayne } \\
\text { et al., 2011) }\end{array}$ \\
\hline & Relapsed/refractory ALL & $\begin{array}{l}\text { Inotuzumab ozogamicin } \\
\text { (CMC-544) with or without } \\
\text { rituximab }\end{array}$ & $\begin{array}{l}\text { Ongoing, } 49 \text { patients } \\
\text { treated (range } \\
6-80 \text { years), } 57 \% \text { ORR }\end{array}$ & M.D. Anderson Cancer Center & $\begin{array}{l}\text { NCT01134575 } \\
\text { Phase I (Kantarjian } \\
\text { et al., 2012) }\end{array}$ \\
\hline & Relapsed ALL & $\begin{array}{l}\text { Epratuzumab associated to } \\
\text { chemotherapy }\end{array}$ & $\begin{array}{l}\text { Ongoing, but not } \\
\text { recruiting participants }\end{array}$ & $\begin{array}{l}\text { National Cancer Institute } \\
\text { (NCl) Multicentric study }\end{array}$ & $\begin{array}{l}\text { NCT00098839 } \\
\text { Phase II }\end{array}$ \\
\hline \multirow[t]{4}{*}{ CD30 } & $\begin{array}{l}\text { Anaplastic large-cell } \\
\text { lymphoma }\end{array}$ & $\begin{array}{l}\text { mAbs SGN-30 associated to } \\
\text { chemotherapy }\end{array}$ & $\begin{array}{l}\text { This study has been } \\
\text { completed }\end{array}$ & National Cancer Institute (NCI) & $\begin{array}{l}\text { NCT00354107 } \\
\text { Phase I/II }\end{array}$ \\
\hline & $\begin{array}{l}\text { HL anaplastic large-cell } \\
\text { lymphoma }\end{array}$ & $\begin{array}{l}\text { Brentuximab vedotin } \\
\text { (SGN-35) }\end{array}$ & $\begin{array}{l}\text { Currently recruiting } \\
\text { participants }\end{array}$ & $\begin{array}{l}\text { Millennium Pharmaceuticals, } \\
\text { Inc. Multicentric study }\end{array}$ & $\begin{array}{l}\text { NCT01492088 } \\
\text { Phase I/II }\end{array}$ \\
\hline & $\begin{array}{l}\text { Hodgkin lymphoma, } \\
\text { large-cell, anaplastic } \\
\text { lymphoma, non-hodgkin }\end{array}$ & & $\begin{array}{l}\text { Approved for sale to the } \\
\text { public }\end{array}$ & $\begin{array}{l}\text { Seattle Genetics, Inc. } \\
\text { Multicentric study }\end{array}$ & NCT01196208 \\
\hline & $\begin{array}{l}\text { ALL, AML, CLL, MM, solid } \\
\text { tumors }\end{array}$ & & $\begin{array}{l}\text { Currently recruiting } \\
\text { participants }\end{array}$ & $\begin{array}{l}\text { Seattle Genetics, Inc. } \\
\text { Multicentric study }\end{array}$ & $\begin{array}{l}\text { NCT01461538 } \\
\text { Phase II }\end{array}$ \\
\hline CD33 & Newly diagnosed AML & Gemtuzumab ozogamicin & Ongoing & $\begin{array}{l}\text { National Cancer Institute } \\
\text { (NCl) Multicentric study }\end{array}$ & $\begin{array}{l}\text { NCT00372593 } \\
\text { Phase III }\end{array}$ \\
\hline CD52 & $\begin{array}{l}\text { Recurrent childhood acute } \\
\text { lymphoblastic leukemia }\end{array}$ & $\begin{array}{l}\text { Alemtuzumab (Campath-1H) } \\
\text { associated to chemotherapy }\end{array}$ & $\begin{array}{l}\text { Limited response: } 8 \% \\
\text { ORR }\end{array}$ & $\begin{array}{l}\text { Children's Oncology Group, } \\
\text { Arcadia, CA, USA }\end{array}$ & $\begin{array}{l}\text { NCT00089349 } \\
\text { Phase II (Angiolillo } \\
\text { et al., 2009) }\end{array}$ \\
\hline
\end{tabular}

CR, complete response; $P R$, partial response; ORR, overall response rate. 
improved GVL effect and increased percentages of WT1-specific cytotoxic T-lymphocytes (CTLs) and no treatment-related adverse events. Nevertheless, the treatment failed to achieve effectiveness in patients with active disease (Hashii et al., 2010, 2012). A trial with DCs pulsed with WT1 is ongoing at NIH (NCT00923910) and adult as well as pediatric patients are being recruited. Unfortunately, despite highly promising, antigen-specific vaccination strategies have shown limited efficacy thus far, especially as single therapies.

The approach of $A C T$ using Tumor Infiltrating Lymphocytes (TIL) (Rosenberg et al., 1986), allogeneic HSCT, or Donor Lymphocyte Infusions (DLI) (Weiden et al., 1981) comprises the powerful features of adaptive immunity and provides GVL effect. In the perspective of defining the best cell population to be infused in patients, since DLI may cause graft-versus-host disease (GvHD), different subsets of CTLs (Montagna et al., 2008), and naturalkiller (NK) (Locatelli et al., 2013) cells have been isolated and studied to define their specificity, toxicity, and in vivo persistence over time. Haploidentical NK cell infusions after an immunosuppressive regimen were well tolerated and resulted in successful engraftment in a pilot study with children affected by AML (Rubnitz et al., 2010). Among novel effector cells, Cytokine-Induced Killer cells (CIK), a peculiar natural-killer like population with a basal anti-tumor activity, are under investigation in clinical trials ${ }^{2}$. In 2007 our group demonstrated that the adoptive transfer of allogeneic CIK cells is feasible under clinical grade conditions and well tolerated (Introna et al., 2007). Similar results were obtained for haploidentical CIK cell infusions in pediatric patients (Rettinger et al., 2013). An open-labeled, multicenter phase II study involving both adult and pediatric patients has been recently concluded with promising results at the highest CIK cell dose infused, with limited toxicity (Introna et al., 2011). Of particular relevance is

${ }^{2}$ http://www.cik-info.org/index.php?kat = ircc-international-registry-on-cikcells the recent identification of the T-stem cell memory ( $\mathrm{T}_{\mathrm{SCM}}$ ) subset with enhanced proliferative and anti-tumor activity. $\mathrm{T}_{\mathrm{SCM}}$ have stem cell-like properties of self-renewal capacity and multipotency (Gattinoni et al., 2011), they can be derived and expanded in vitro, offering a promising platform of cellular production for future translation in clinic (Cieri et al., 2013).

\section{CANCER IMMUNOTHERAPY WITH GENE TRANSFER: TCR AND CAR}

Unmanipulated T- or NK-cells have proven to have several limitations after infusion both in terms of limited activity and poor long-term survival. Therefore, in the last years, there has been considerable interest in the development of fine strategies of gene transfer to genetically manipulate immune cells and improve their anti-tumor immune responses in vivo. In this context, artificial T-cell receptors (TCR) and Chimeric Antigen Receptors (CARs) have been generated to redirect effector immune cells specifically against TAAs (Gross et al., 1989; Clay et al., 1999).

Transfer of engineered $\mathrm{T}$ cells with artificial high-affinity TCR derived from $\alpha$ and $\beta$ chains isolated from patients has been used in successful clinical trials by Rosenberg and collaborators, targeting MART1 (Morgan et al., 2006) or NY-ESO-1 (Robbins et al., 2011) for the treatment of melanoma and synovial cell sarcoma. However, since this approach is limited by tumor escape mechanisms, scientific efforts were taken for optimizing the functionality of the artificial TCR. Notably, an emerging technical advance concerning this strategy has been recently reported: TCR editing was optimized by zinc-finger nucleases that eliminate the risk of TCR mispairing with endogenous $\alpha$ and $\beta$ chains, which would otherwise cause an unpredictable and thus not safe specificity (Provasi et al., 2012).

Chimeric antigen receptors are chimeric TCR that are artificially constituted by an antigen-recognizing extracellular domain derived from an antibody, linked to a T-cell triggering domain and are introduced in effector $\mathrm{T}$ cells to redirect their activity

Table 2 | Ongoing pediatric clinical trials using CARs.

\begin{tabular}{|c|c|c|c|c|c|}
\hline Target & Malignancies & Intervention & Results & Location & $\begin{array}{l}\text { Trial number } \\
\text { and references }\end{array}$ \\
\hline CD19 & ALL & $\begin{array}{l}\text { Anti-CD } 19 \text { CAR donor } \\
\text { EBV-CTL post-HSCT with } \\
\text { EBV-CTL vaccine }\end{array}$ & Currently recruiting participants & $\begin{array}{l}\text { University College of } \\
\text { London Multicentric study }\end{array}$ & $\begin{array}{l}\text { NCT01195480 } \\
\text { Phase I/II }\end{array}$ \\
\hline CD19 & ALL & $\begin{array}{l}\text { Anti-CD } 19 \text { CAR donor } \\
\text { EBV-CTL post-HSCT }\end{array}$ & $\begin{array}{l}\text { Currently recruiting participants, } \\
\text { three patients treated without } \\
\text { GvHD after infusion }\end{array}$ & $\begin{array}{l}\text { Memorial Sloan-Kettering } \\
\text { Cancer Center }\end{array}$ & $\begin{array}{l}\text { NCT01430390 } \\
\text { Phase I (Curran } \\
\text { et al., 2012) }\end{array}$ \\
\hline CD19 & $\begin{array}{l}\text { B-cell malignancy: ALL, } \\
\text { B-cell lymphoma, leukemia } \\
\text { large-cell lymphoma, NHL }\end{array}$ & $\begin{array}{l}\text { Anti-CD } 19 \text { CAR } \\
\text { autologous PBL }\end{array}$ & $\begin{array}{l}\text { Currently recruiting participants, } \\
\text { one CR pediatric ALL patient } \\
\text { after a mild CRS }\end{array}$ & National Cancer Institute & $\begin{array}{l}\text { NCT01593696 } \\
\text { Phase I (Lee } \\
\text { et al., 2012b) }\end{array}$ \\
\hline CD19 & $\begin{array}{l}\text { B-cell leukemia, B-cell } \\
\text { lymphoma }\end{array}$ & $\begin{array}{l}\text { Pedi CART-19: anti-CD } 19 \\
\text { CAR second generation } \\
\text { (4-1BB) autologous PBL }\end{array}$ & $\begin{array}{l}\text { Currently recruiting participants, } \\
\text { two CR pediatric ALL patients }\end{array}$ & $\begin{array}{l}\text { Children's Hospital of } \\
\text { Philadelphia/University of } \\
\text { Pennsylvania }\end{array}$ & $\begin{array}{l}\text { NCT01626495 } \\
\text { (Grupp et al., } \\
\text { 2013) }\end{array}$ \\
\hline CD19 & B-cell leukemia & $\begin{array}{l}\text { Anti-CD } 19 \text { CAR first } \\
\text { generation autologous PBL }\end{array}$ & Currently recruiting participants & Seattle Children's Hospital & $\begin{array}{l}\text { NCT01683279 } \\
\text { Phase I }\end{array}$ \\
\hline
\end{tabular}


toward TAA (Gross et al., 1989). In contrast to artificial TCR strategy, target recognition by CAR molecules is non-HLA restricted and independent of antigen processing, bypassing HLA-molecule down-regulation. Although the first clinical trials with CAR demonstrated the feasibility of this approach to target hematological malignancies in terms of safety and tolerability, they also highlighted the need to improve the in vivo persistence of the transferred T cells (Till et al., 2008). Therefore, second and third generation CARs have been developed, by addition of one or two co-stimulatory molecules (Lee et al., 2012a).

To enhance the survival and activity of modified T cells, expression of CAR or TCR was performed in Epstein Barr Virus (EBV)specific CTLs. Due to their dual specificity longer cell survival and enhanced tumor regression were achieved, as a result of the continuous engagement of the native (EBV-specific) TCR on professional APCs (Pule et al., 2008). However, these approaches still need to be implemented in terms of efficacy and safety (Park et al., 2011) since serious adverse events due to "on-target but off-organ" toxicity occurred in two clinical trials with CARs targeting HER2 and CD19 (Heslop, 2010). The introduction of suicide genes, such as inducible Casp9, within the engineered T cells could be an additional back-up control in case of adverse effects (Di Stasi et al., 2011) and a clinical trial is ongoing to treat patients developing GVHD after HSCT (NCT00710892).

Nowadays we are witnessing a new era of ACT, when recent successes in clinical trials with CAR reinforced the potential therapeutic benefit of this approach. Several clinical trials are ongoing in pediatric patients, starting from evidence of tumor regression in four out of eight patients belonging to studies with EBV-specific CTLs expressing GD2-specific CARs for the treatment of neuroblastoma (Pule et al., 2008) (NCT01460901). Table 2 summarizes the main pediatric clinical trials with CAR for the treatment of hematological malignancies that are actually ongoing. A trial with CD19-targeting CAR EBV-specific T cells showed important preliminary results suggesting the feasibility of this approach without infusion-related toxicity (Curran et al., 2012). Notably, Grupp and collaborators recently reported induction of remission followed by B-cell aplasia and Cytokine Release Syndrome (CRS) in two pediatric patients with relapsed, refractory pre-B-cell ALL treated with CD19-specific CAR T cells. In one patient CRS was controlled by administration of the IL- 6 antagonist Tocilizumab and remission is still ongoing whereas the other patient relapsed with the emergence of CD19-negative blasts (Grupp et al., 2013). Our group has been involved in the "CHILDHOPE" program, a translational research project focused on the treatment of childhood ALL, lymphoma, and AML with CD19- and CD33-specific CARs, respectively ${ }^{3}$. Furthermore, for the treatment of AML, we are currently

\footnotetext{
${ }^{3}$ www.childhope.eu
}

\section{REFERENCES}

Acharya, S., and Sahoo, S. K. (2011). PLGA nanoparticles containing various anticancer agents and tumour delivery by EPR effect. Adv. Drug Deliv. Rev. 63, 170-183.
Angiolillo, A. L., Yu, A. L., Reaman, G., Ingle, A. M., Secola, R., and Adamson, P. C. (2009). A phase II study of Campath-1H in children with relapsed or refractory acute lymphoblastic leukemia: a Children's

investigating the targeting of CD123 antigen in order to improve the specificity and safety of the CAR approach (Tettamanti et al., 2013).

\section{FUTURE PERSPECTIVES}

The recent efficacy of targeted therapies has changed our perspective of leukemia treatment. New-generation small molecules, such as Dasatinib and lately designed mAbs, such as Inotuzumab or BiTe represent major progress toward cure, but their success is partially eclipsed by the drawbacks of resistance or transient response to therapy (Walz et al., 2006). Advanced protocols of gene and ACT may help to overcome these limitations. Actually, these approaches should promote long-term efficacy, maintaining specificity with reduced toxicity. Moreover, improvements in novel technologies of drug delivery, such as nanoparticles (Acharya and Sahoo, 2011), or easier and more efficient methods of gene transfer, such as transposons (Izsvak et al., 2009), should further ameliorate the range of applications of these novel therapies. Indeed, a new phase I clinical trial with genetically modified human $\mathrm{T}$ cells expressing anti-CD19. CAR using the Sleeping Beauty transposon system is actually ongoing in patients with high-risk B-lymphoid malignancies (Kebriaei et al., 2012).

The scenario that we expect to see in the next future is the development of advanced protocols in the context of "consolidative therapy." Immunotherapy by gene-redirected immune cells will provide the potential of controlling MRD in patients following initial chemotherapy or HSCT, behaving as a "longlasting living" drugs, contrarily to standard chemotherapy agents or mAbs. Phase I and II clinical trials are currently combining chemotherapy and HSCT with targeted therapy or immunotherapy for patients who failed standard treatments. These studies will assess safety, efficacy, and feasibility in applying such combined approaches. The next step will be the definition of the best timing schedule and dosing regimen in patients that will truly benefit from these immuno-genetherapy approaches. Over the next decade, clinicians and scientists will have the unique chance to witness the effects of advanced treatments in pediatric patients affected by hematological malignancies.

\section{ACKNOWLEDGMENTS}

A particular gratitude goes to Riccardo and Donatella, a patient's parents, who generously support C.F.M. fellowship, and to Silvia Arcangeli, Alessandro Palazzin, and Georgia Fousteri for support. This work was supported by grants from STREP 2006 (6th framework; LSHC -CT-2006- 037381): "Chimeric T cells for the treatment of pediatric cancers (Childhope)." See: www.childhope.eu; "AIRC Molecular Clinical Oncology 5 per mille," "Innate immunity in cancer. Molecular targeting and cellular therapy," 9962; "Libera Le Ali” 2011 project, Fondazione Just Italia.

Oncology Group report. Pediatr. Blood Cancer 53, 978-983.

Aplenc, R., Blaney, S. M., Strauss, L. C., Balis, F. M., Shusterman, S., Ingle, A. M., et al. (2011). Pediatric phase I trial and pharmacokinetic study of dasatinib: a report from the children's oncology group phase I consortium. J. Clin. Oncol. 29, 839-844.

Arora, A., and Scholar, E. M. (2005). Role of tyrosine kinase inhibitors in 
cancer therapy. J. Pharmacol. Exp. Ther. 315, 971-979.

Cieri, N., Camisa, B., Cocchiarella, F., Forcato, M., Oliveira, G., Provasi, E., et al. (2013). IL-7 and IL-15 instruct the generation of human memory stem $\mathrm{T}$ cells from naive precursors. Blood 121, 573-584.

Clay, T. M., Custer, M. C., Sachs, J., Hwu, P., Rosenberg, S. A., and Nishimura, M. I. (1999). Efficient transfer of a tumor antigenreactive TCR to human peripheral blood lymphocytes confers antitumor reactivity. J. Immunol. 163, 507-513.

Curran, K. J., Kernan, N. A., Wang, X., Taylor, C., Doubrovina, E., Bartido, S., et al. (2012). CD19 targeted allogeneic EBV-specific T cells for the treatment of relapsed ALL in pediatric patients post HSCT. ASH Annual Meeting Abstracts 120, Atlanta, 353.

Di Stasi, A., Tey, S. K., Dotti, G., Fujita, Y., Kennedy-Nasser, A., Martinez, C., et al. (2011). Inducible apoptosis as a safety switch for adoptive cell therapy. N. Engl. J. Med. 365, 1673-1683.

Dougan, M., and Dranoff, G. (2009). Immune therapy for cancer. Annu. Rev. Immunol. 27, 83-117.

Dworzak, M. N., Schumich, A., Printz, D., Potschger, U., Husak, Z., Attarbaschi, A., et al. (2008). CD20 up-regulation in pediatric B-cell precursor acute lymphoblastic leukemia during induction treatment: setting the stage for antiCD20 directed immunotherapy. Blood 112, 3982-3988.

Fabbro, D., Ruetz, S., Bodis, S., Pruschy, M., Csermak, K., Man, A., et al. (2000). PKC412 - a protein kinase inhibitor with a broad therapeutic potential. Anticancer Drug Des. 15, $17-28$.

FitzGerald, D. J., Wayne, A. S., Kreitman, R. J., and Pastan, I. (2011). Treatment of hematologic malignancies with immunotoxins and antibodydrug conjugates. Cancer Res. 71, 6300-6309.

Gattinoni, L., Lugli, E., Ji, Y., Pos, Z., Paulos, C. M., Quigley, M. F., et al. (2011). A human memory $\mathrm{T}$ cell subset with stem cell-like properties. Nat. Med. 17, 1290-1297.

Gore, L., Macy, M. E., Mechinaud, F., Narendran, A., Alvaro, F., Arndt, C. A. S., et al. (2012). Interim report of a randomized, open-label, multicenter study to evaluate the safety and efficacy of decitabine as an epigenetic priming agent when combined with induction chemotherapy in pediatric patients (pts) with newly diagnosed acute myelogenous leukemia (AML). ASH Annual Meeting Abstracts 120, Atlanta, 1517.

Griffin, T. C., Weitzman, S., Weinstein, H., Chang, M., Cairo, M., Hutchison, R., et al. (2009). A study of rituximab and ifosfamide, carboplatin, and etoposide chemotherapy in children with recurrent/refractory B-cell $(\mathrm{CD} 20+)$ non-Hodgkin lymphoma and mature B-cell acute lymphoblastic leukemia: a report from the Children's Oncology Group. Pediatr. Blood Cancer 52, 177-181.

Gross, G., Waks, T., and Eshhar, Z. (1989). Expression of immunoglobulin-T-cell receptor chimeric molecules as functional receptors with antibody-type specificity. Proc. Natl. Acad. Sci. U.S.A. 86, 10024-10028.

Grupp, S. A., Kalos, M., Barrett, D., Aplenc, R., Porter, D. L., Rheingold, S. R., et al. (2013). Chimeric antigen receptor-modified $\mathrm{T}$ cells for acute lymphoid leukemia. N. Engl. J. Med. 368, 1509-1518.

Hashii, Y., Sato, E., Ohta, H., Oka, Y., Sugiyama, H., and Ozono, K. (2010). WT1 peptide immunotherapy for cancer in children and young adults. Pediatr. Blood Cancer 55, 352-355.

Hashii, Y., Sato-Miyashita, E., Matsumura, R., Kusuki, S., Yoshida, H., Ohta, H., et al. (2012). WT1 peptide vaccination following allogeneic stem cell transplantation in pediatric leukemic patients with high risk for relapse: successful maintenance of durable remission. Leukemia 26, 530-532.

Heslop, H. E. (2010). Safer CARS. Mol. Ther. 18, 661-662.

Hijiya, N., Gaynon, P., Barry, E., Silverman, L., Thomson, B., Chu, R., et al. (2009). A multi-center phase I study of clofarabine, etoposide and cyclophosphamide in combination in pediatric patients with refractory or relapsed acute leukemia. Leukemia 23, 2259-2264.

Hijiya, N., Thomson, B., Isakoff, M. S., Silverman, L. B., Steinherz, P. G., Borowitz, M. J., et al. (2011). Phase 2 trial of clofarabine in combination with etoposide and cyclophosphamide in pediatric patients with refractory or relapsed acute lymphoblastic leukemia. Blood 118, 6043-6049.

Hunter, T. (1998). The role of tyrosine phosphorylation in cell growth and disease. Harvey Lect. 94, 81-119.

Inaba, H., Rubnitz, J. E., Coustan-Smith, E., Li, L., Furmanski, B. D., Mascara, G. P., et al. (2011). Phase I pharmacokinetic and pharmacodynamic study of the multikinase inhibitor sorafenib in combination with clofarabine and cytarabine in pediatric relapsed/refractory leukemia. $J$. Clin. Oncol. 29, 3293-3300.

Introna, M., Algarotti, A., Mico, C., Grassi, A., Pievani, A., Borleri, G. et al. (2011). A phase II study of sequential administration of DLI and cytokine induced killer (CIK) cells in patients with hematologic malignancies relapsing after allogeneic hematopoietic stem cell transplantation: preliminary results. ASH Annual Meeting Abstracts 118, San Diego, 657.

Introna, M., Borleri, G., Conti, E., Franceschetti, M., Barbui, A. M., Broady, R., et al. (2007). Repeated infusions of donorderived cytokine-induced killer cells in patients relapsing after allogeneic stem cell transplantation: a phase I study. Haematologica 92, 952-959.

Izsvak, Z., Chuah, M. K., Vandendriessche, T., and Ivics, Z. (2009). Efficient stable gene transfer into human cells by the Sleeping Beauty transposon vectors. Methods 49, 287-297.

Jeha, S., Gandhi, V., Chan, K. W., McDonald, L., Ramirez, I., Madden, R., et al. (2004). Clofarabine, a novel nucleoside analog, is active in pediatric patients with advanced leukemia. Blood 103, 784-789.

Jeha, S., Gaynon, P. S., Razzouk, B. I., Franklin, J., Kadota, R., Shen, V., et al. (2006). Phase II study of clofarabine in pediatric patients with refractory or relapsed acute lymphoblastic leukemia. J. Clin. Oncol. 24, 1917-1923.

Kantarjian, H., Thomas, D., Jorgensen, J., Jabbour, E., Kebriaei, P., Rytting, M., et al. (2012). Inotuzumab ozogamicin, an anti$\mathrm{CD} 22 \hat{a} \neq$ calicheamicin conjugate, for refractory and relapsed acute lymphocytic leukaemia: a phase 2 study. Lancet Oncol. 13, 403-411.

Kantarjian, H. M., Jeha, S., Gandhi, V., Wess, M., and Faderl, S. (2007). Clofarabine: past, present, and future. Leuk. Lymphoma 48, 1922-1930.

Kebriaei, P., Huls, H., Jena, B., Munsell, M., Jackson, R., Lee, D. A., et al. (2012). Infusing CD19-directed $\mathrm{T}$ cells to augment disease control in patients undergoing autologous hematopoietic stem-cell transplantation for advanced B-lymphoid malignancies. Hum. Gene Ther. 23, 444-450.

Law, J., Cowan, M. J., Dvorak, C. C., Musick, L., Long-Boyle, J. R., Baxter-Lowe, L. A., et al. (2012). Busulfan, fludarabine, and alemtuzumab as a reduced toxicity regimen for children with malignant and nonmalignant diseases improves engraftment and graft-versus-host disease without delaying immune reconstitution. Biol. Blood Marrow Transplant. 18, 1656-1663.

Lee, D. W., Barrett, D. M., Mackall, C., Orentas, R., and Grupp, S. A. (2012a). The future is now: chimeric antigen receptors as new targeted therapies for childhood cancer. Clin. Cancer Res. 18, 2780-2790.

Lee, D. W. III, Stetler-Stevenson, M., Sabatino, M., Tumaini, B., Richards, K., Delbrook, C., et al. (2012b). Autologous-collected donor-derived CD19-directed chimeric antigen receptor (CD19-CAR) $\mathrm{T}$ cells induce a complete remission in chemotherapy-refractory childhood acute lymphocytic leukemia (ALL) relapsing after allogeneic hematopoietic stem cell transplantation (HSCT). ASH Annual Meeting Abstracts 120, Atlanta, 2609.

Lee-Sherick, A. B., Linger, R. M., Gore, L., Keating, A. K., and Graham, D. K. (2010). Targeting paediatric acute lymphoblastic leukaemia: novel therapies currently in development. Br. J. Haematol. 151, 295-311.

Leung, W., Campana, D., Yang, J., Pei, D., Coustan-Smith, E., Gan, K., et al. (2011). High success rate of hematopoietic cell transplantation regardless of donor source in children with very high-risk leukemia. Blood 118, 223-230.

Levis, M., Allebach, J., Tse, K. F., Zheng, R., Baldwin, B. R., Smith, B. D., et al. (2002). A FLT3-targeted tyrosine kinase inhibitor is cytotoxic to leukemia cells in vitro and in vivo. Blood 99, 3885-3891.

Levis, M., and Small, D. (2003). FLT3: ITDoes matter in leukemia. Leukemia 17, 1738-1752.

Locatelli, F., Pende, D., Mingari, M. C., Bertaina, A., Falco, M., Moretta, A., et al. (2013). Cellular and molecular basis of haploidentical hematopoietic stem cell transplantation in the successful treatment of highrisk leukemias: role of alloreactive NK cells. Front. Immunol. 4:15. doi:10.3389/fimmu.2013.00015

Locatelli, F., Schrappe, M., Bernardo, M. E., and Rutella, S. (2012). How I treat relapsed childhood acute lymphoblastic leukemia. Blood 120, 2807-2816.

Locatelli, F., Testi, A. M., Bernardo, M. E., Rizzari, C., Bertaina, A. Merli, P., et al. (2009). Clofarabine, cyclophosphamide and etoposide as single-course re-induction therapy for children with refractory/multiple relapsed acute lymphoblastic leukaemia. Br. J. Haematol. 147, 371-378. 
Mackall, C. L. (2011). In search of targeted therapies for childhood cancer. Front. Oncol. 1:18. doi:10.3389/fonc.2011.00018

May, C., Sapra, P., and Gerber, H. P. (2012). Advances in bispecific biotherapeutics for the treatment of cancer. Biochem. Pharmacol. 84, 1105-1112.

Meinhardt, A., Burkhardt, B., Zimmermann, M., Borkhardt, A., Kontny, U., Klingebiel, T., et al. (2010). Phase II window study on rituximab in newly diagnosed pediatric mature Bcell non-Hodgkin's lymphoma and Burkitt leukemia. J. Clin. Oncol. 28, 3115-3121.

Montagna, D., Maccario, R., and Locatelli, F. (2008). Expansion of antileukaemia CTL lines and clones for adoptive cell therapy in paediatric patients given allogeneic haematopoietic stem cell transplantation. Int. J. Immunogenet. 35, 389-393.

Montgomery, J. A., Shortnacy-Fowler, A. T., Clayton, S. D., Riordan, J. M., and Secrist, J. A. III. (1992). Synthesis and biologic activity of $2^{\prime}$ fluoro-2-halo derivatives of 9-betaD-arabinofuranosyl adenine. J. Med. Chem. 35, 397-401.

Morgan, R. A., Dudley, M. E., Wunderlich, J. R., Hughes, M. S., Yang, J. C., Sherry, R. M., et al. (2006). Cancer regression in patients after transfer of genetically engineered lymphocytes. Science 314, 126-129.

O'Brien, S. G., Guilhot, F., Larson, R. A., Gathmann, I., Baccarani, M., Cervantes, F., et al. (2003). Imatinib compared with interferon and low-dose cytarabine for newly diagnosed chronic-phase chronic myeloid leukemia. N. Engl. J. Med. 348, 994-1004.

Olivieri, A., and Manzione, L. (2007). Dasatinib: a new step in molecular target therapy. Ann. Oncol. 18(Suppl. 6), vi42-vi46.

Orentas, R. J., Lee, D. W., and Mackall, C. (2012). Immunotherapy targets in pediatric cancer. Front. Oncol. 2:3. doi:10.3389/fonc.2012.00003

Park, T. S., Rosenberg, S. A., and Morgan, R. A. (2011). Treating cancer with genetically engineered $\mathrm{T}$ cells. Trends Biotechnol. 29, 550-557.

Pinto, A., Maio, M., Attadia, V., Zappacosta, S., and Cimino, R. (1984). Modulation of HLA-DR antigens expression in human myeloid leukaemia cells by cytarabine and 5-aza-2'-deoxycytidine. Lancet 2, 867-868.

Provasi, E., Genovese, P., Lombardo, A., Magnani, Z., Liu, P. Q., Reik, A., et al. (2012). Editing T cell specificity towards leukemia by zinc finger nucleases and lentiviral gene transfer. Nat. Med. 18, 807-815.

Pule, M. A., Savoldo, B., Myers, G. D., Rossig, C., Russell, H. V., Dotti, G., et al. (2008). Virus-specific T cells engineered to coexpress tumorspecific receptors: persistence and antitumor activity in individuals with neuroblastoma. Nat. Med. 14, 1264-1270.

Redaelli, S., Piazza, R., Rostagno, R., Magistroni, V., Perini, P., Marega, M., et al. (2009). Activity of bosutinib, dasatinib, and nilotinib against 18 imatinib-resistant BCR/ABL mutants. J. Clin. Oncol. 27, 469-471.

Rettinger, E., Bonig, H., Wehner, S., Lucchini, G., Willasch, A., Jarisch, A., et al. (2013). Feasibility of IL-15-activated cytokineinduced killer cell infusions after haploidentical stem cell transplantation. Bone Marrow Transplant. doi:10.1038/bmt.2013.19. [Epub ahead of print].

Robbins, P. F., Morgan, R. A., Feldman, S. A., Yang, J. C., Sherry, R. M., Dudley, M. E., et al. (2011). Tumor regression in patients with metastatic synovial cell sarcoma and melanoma using genetically engineered lymphocytes reactive with NY-ESO-1. J. Clin. Oncol. 29, 917-924.

Rosenberg, S. A., Spiess, P., and Lafreniere, R. (1986). A new approach to the adoptive immunotherapy of cancer with tumor-infiltrating lymphocytes. Science 233, 1318-1321.

Rousseau, R. F., and Brenner, M. K. (2005). Vaccine therapies for pediatric malignancies. Cancer J. 11, 331-339.

Rubnitz, J. E. (2012). How I treat pediatric acute myeloid leukemia. Blood 119, 5980-5988.

Rubnitz, J. E., Inaba, H., Ribeiro, R. C., Pounds, S., Rooney, B., Bell, T., et al. (2010). NKAML: a pilot study to determine the safety and feasibility of haploidentical natural killer cell transplantation in childhood acute myeloid leukemia. J. Clin. Oncol. 28, 955-959.

Schafer, E., Irizarry, R., Negi, S., McIntyre, E., Small, D., Figueroa, M. E., et al. (2010). Promoter hypermethylation in MLL-R infant acute lymphoblastic leukemia: biology and therapeutic targeting. Blood 115, 4798-4809.

Schultz, K. R., Bowman, W. P., Aledo, A., Slayton, W. B., Sather, H., Devidas, M., et al. (2009). Improved early event-free survival with imatinib in Philadelphia chromosome-positive acute lymphoblastic leukemia: a children's oncology group study. J. Clin. Oncol. 27, 5175-5181.

Scott, A. M., Wolchok, J. D., and Old, L. J. (2012). Antibody therapy of cancer. Nat. Rev. Cancer 12, 278-287.

Sharkey, R. M., and Goldenberg, D. M. (2011). Cancer radioimmunotherapy. Immunotherapy 3, 349-370.

Slayton, W. B., Schultz, K. R., Jones, T., Raetz, E., Devidas, M., Pulsipher, M. A., et al. (2012). Continuous dose dasatinib is safe and feasible in combination with intensive chemotherapy in pediatric philadelphia chromosome positive acute lymphoblastic leukemia $(\mathrm{Ph}+\mathrm{ALL})$ : Children's Oncology Group (COG) trial AALL0622. ASH Annual Meeting Abstracts 120, Atlanta, 137.

Tettamanti, S., Marin, V., Pizzitola, I. Magnani, C. F., Giordano Attianese, G. M., Cribioli, E., et al. (2013). Targeting of acute myeloid leukaemia by cytokine-induced killer cells redirected with a novel CD123-specific chimeric antigen receptor. $\mathrm{Br}$. J. Haematol. 161, 389-401.

Till, B. G., Jensen, M. C., Wang, J., Chen, E. Y., Wood, B. L., Greisman, H. A., et al. (2008). Adoptive immunotherapy for indolent non-Hodgkin lymphoma and mantle cell lymphoma using genetically modified autologous CD20-specific T cells. Blood 112, 2261-2271.

Unguru, Y. (2011). The successful integration of research and care: how pediatric oncology became the subspecialty in which research defines the standard of care. Pediatr. Blood Cancer 56, 1019-1025.

Villanueva, M. T. (2012). Targeted therapies: smart tumor, smarter treatment. Nat. Rev. Clin. Oncol. 9, 127.

Walz, C., Curtis, C., Schnittger, S. Schultheis, B., Metzgeroth, G., Schoch, C., et al. (2006). Transient response to imatinib in a chronic eosinophilic leukemia associated with ins(9;4)(q33;q12q25) and a CDK5RAP2-PDGFRA fusion gene. Genes Chromosomes Cancer 45, 950-956.

Wassmann, B., Pfeifer, H., Scheuring, U. J., Binckebanck, A., Gokbuget, N., Atta, J., et al. (2004). Early prediction of response in patients with relapsed or refractory Philadelphia chromosome-positive acute lymphoblastic leukemia (Ph+ALL) treated with imatinib. Blood 103, 1495-1498.

Wayne, A. S., Bhojwani, D., Silverman, L. B., Richards, K., Stetler-Stevenson, M., Shah, N. N., et al. (2011). A novel anti-CD22 immunotoxin, moxetumomab pasudotox: phase I study in pediatric acute lymphoblastic leukemia (ALL). ASH Annual Meeting Abstracts 118, San Diego, 248.

Wayne, A. S., Capitini, C. M., and Mackall, C. L. (2010). Immunotherapy of childhood cancer: from biologic understanding to clinical application. Curr. Opin. Pediatr. 22, 2-11.

Wayne, A. S., Reaman, G. H., and Helman, L. J. (2008). Progress in the curative treatment of childhood hematologic malignancies. J. Natl. Cancer Inst. 100, 1271-1273.

Weiden, P. L., Sullivan, K. M., Flournoy, N., Storb, R., and Thomas, E. D. (1981). Antileukemic effect of chronic graft-versus-host disease: contribution to improved survival after allogeneic marrow transplantation. N. Engl. J. Med. 304, 1529-1533.

Weisberg, E., Manley, P. W., Breitenstein, W., Bruggen, J., CowanJacob, S. W., Ray, A., et al. (2005). Characterization of AMN107, a selective inhibitor of native and mutant Bcr-Abl. Cancer Cell 7, 129-141.

Younes, A., Bartlett, N. L., Leonard, J. P., Kennedy, D. A., Lynch, C. M., Sievers, E. L., et al. (2010). Brentuximab vedotin (SGN35) for relapsed CD30-positive lymphomas. N. Engl. J. Med. 363, 1812-1821.

Conflict of Interest Statement: The authors declare that the research was conducted in the absence of any commercial or financial relationships that could be construed as a potential conflict of interest.

Received: 30 January 2013; accepted: 15 April 2013; published online: 30 April 2013.

Citation: Magnani CF, Tettamanti S, Maltese F, Turazzi N, Biondi $A$ and Biagi E (2013) Advanced targeted, cell and gene-therapy approaches for pediatric hematological malignancies: results and future perspectives. Front. Oncol. 3:106. doi: 10.3389/fonc.2013.00106

This article was submitted to Frontiers in Pediatric Oncology, a specialty of Frontiers in Oncology.

Copyright () 2013 Magnani, Tettamanti, Maltese, Turazzi, Biondi and Biagi. This is an open-access article distributed under the terms of the Creative Commons Attribution License, which permits use, distribution and reproduction in other forums, provided the original authors and source are credited and subject to any copyright notices concerning any third-party graphics etc. 